ВОЛОНТЕРСТВО ЯК СОЦІАЛЬНО-ПСИХОЛОГІЧНА ХАРАКТЕРИСТИКА ОСОБИСТОСТІ

\title{
VOLUNTEERING AS A SOCIO-PSYCHOLOGICAL CHARACTERISTICS OF PERSONALITY
}

у статті йдеться про проблему розроблення соціально-психологічного портрета волонтера. Волонтерство та характеристика учасників добровольчого руху представлені через постулати концепції педагогіки спільної діяльності, аспекти освіти суб'єктів добровольчої діяльності як умови, в яких добровольчі мають можливість ініціювати власну спільну добровольчу діяльність, визначати вектор ії розвитку, стаючи суб'єктами власного особистісного світу. Виділено характеристики комплексу організаційно-педагогічних умов шляхом концентрації потенціалу добровольчої діяльності молоді. Волонтерство розглянуто як процес залучення в нефрормальну громадську діяльність людей різного соціального статусу і віку, а особливий світогляд заснований на ідеях безкорисливого служіння гуманним ідеалам людства $і$ громадським інтересам. Волонтерський рух, сильно поширений у країнах Європи і США, розвивається нині в Україні, спираючись не тільки на світовий досвід, але й на вітчизняні традиції волонтерства та благодійництва. Волонтерська діяльність може бути спрямована на досягнення педагогічних цілей, стати важливим фрактором виховання дітей і молоді. Педагогічне волонтерство розглядається як взаємодія педагогів, добровольців із представниками підростаючого покоління, які потребують комплексної допомоги під час вирішення проблем становлення і саморозвитку особистості. Найбільш продуктивне завдання педагогічного волонтерства вирішується в рамках дитячо-молодіжних громадських об'єднань, $є$ найбільш стабільною i структурованою частиною педагогічної підтримки, соціальними інститутами виховання. Описано сучасний виховний процес, що включає педагогічне волонтерство, яке вимагає наявності системної роботи з дітьми та молоддю щодо формування в них позитивного соціального досвіду, комплексу зовнішніх і внутрішніх умов (педагогічних психологічних, соціальних), що реалізуються через програму дій фрахівців різного просрілю та $\epsilon$ аналогом моделі організації волонтерської діяльності. Найважливішим компонентом такої моделі та умовою ефективності роботи з підлітками, які мають труднощі в соціалізації, виступає створення стійкої пари «волонтер - вихованець». Під терміном «волонтерство» розуміється неоплачувана, свідома, добровільна діяльність на благо інших. В останнє десятиліття розвивається практика залучення праці добровольців у педагогічну роботу з дітьми. Громадські інститути та педагогіка завжди консолідували свої зусилля для створення практично діючих моделей виховання дітей, оскільки сам об'єкт впливу, а саме підростаюче покоління, передбачав введення педагогічного компонента у вирішення завдань виживання й захисту дітей, а специфріка освітньої діяльності щодо соціально непривілейованих груп дітей передбачала одночасне вирішення завдань соціального захисту.

Ключові слова: волонтерство, молодь, благодійність, соціалізація, соціум, адаптація.

The article deals with the problem of developing a socio-psychological portrait of a volunteer. The article presents volunteering and the characteristics of members of the voluntary movement presented through the postulates of the concept of pedagogy of joint activities, aspects of education of volunteering as a condition in which volunteers have the opportunity to initiate their own joint volunteering, determine the vector of its development, thus becoming subjects of their own personal world. The characteristics of the complex of organizational and pedagogical conditions, concentrating the potential of voluntary activity of youth are highlighted. Volunteering is seen as a process of involving people of different social status and age in informal social activities, a special worldview based on the ideas of selfless service to the humane ideals of mankind and public interests. The volunteer movement, widespread in Europe and the United States, is currently developing in Ukraine, based not only on world experience but also on domestic traditions of volunteering and philanthropy. Volunteering can be aimed at achieving pedagogical goals, to become an important factor in the education of children and youth. Pedagogical volunteering is seen as the interaction of teachers, volunteers with the younger generation, who need comprehensive assistance in solving problems of formation and self-development of the individual. The most productive task of pedagogical volunteering is solved within the framework of children's and youth public associations, is the most stable and structured part of pedagogical support, social institutions of education. Describes the modern educational process, including pedagogical volunteering which requires a system of work with children and youth to form their positive social experience, a set of external and internal conditions (pedagogical, psychological, social), implemented through the program of actions of specialists of various profiles which is analogous to the model of volunteering. The most important component of such a model and a condition for the effectiveness of work with adolescents, who have difficulties in socialization, is the creation of a stable pair of "volunteer - pupil". The term "volunteering" refers to unpaid, conscious, voluntary activities for the benefit of others. In the last decade, the practice of involving volunteers in pedagogical work with children has been developing. Public institutions and pedagogy have always consolidated their efforts to create practical models of child rearing, as the object of influence - the younger generation provided for the introduction of a pedagogical component in solving problems of survival and protection of children, and the specifics of educational activities for socially disadvantaged groups social protection tasks.

Key words: volunteering, youth, charity, socialization, society, adaptation. навчально-реабілітаційний соціально-економічний коледж 
Постановка проблеми. Волонтер - це людина, яка займається суспільно корисними справами, не отримуючи за це оплати. Отже, така діяльність не може вважатися професійною, тобто вона не приносить гроші на прожиття. Добровольці витрачають свій особистий час, щоб допомогти іншим людям. Термін волонтерство походить від латинського слова "voluntaris", що означає «добровільний».

Аналіз останніх досліджень і публікацій. Волонтерство як соціокультурний феномен вивчається істориками, психологами, юристами, економістами, фахівцями в галузі соціальної педагогіки, соціальної роботи, соціального менеджменту, соціальної психології тощо. Ми розглядаємо педагогічні аспекти волонтерства, його соціально-культурні технології та технології навчання, специфіку організації волонтерства серед підлітків і молоді як практики, що забезпечує успішність їхньої соціалізації. Залучення волонтерства в комплекс соціальної роботи, обговорюване в науковій літературі, зумовлене специфікою професійного поля, історичними передумовами виникнення та інституціоналізації цієї роботи, спільністю альтруїстичних підстав, що лежать як в її основі, таків базовихпринципахволонтерства. При цьому часто акцентується увага на трудовому підході та економічних дослідженнях ефективності волонтерської праці, пов'язаних із вивченням його функцій у суспільстві; вивчається мотивація волонтерства, що дає змогу виявляти його психологічні детермінанти.

Постановка завдання. Мета дослідження полягає в розробленні стратегії емпіричного вивчення психологічних особливостей особистості волонтерів та виділенні факторів, які $є$ значущими для молоді, яка бере участь у волонтерському русі.

Виклад основного матеріалу дослідження. Волонтерство - це безоплатна діяльність особи, метою якої є допомога людині, яка має у цьому потребу. Кластерний аналіз дав змогу визначити сильні (домінантні) комбінації комплексу характеристик, властивих волонтерам, такі як милосердя, відповідальність, турбота, любов, чуйність.

Різкі трансформаційні зміни ставлення до волонтерства в різних сферах суспільного життя за відсутності комплексних наукових досліджень, мотиваційних підстав, емоційних аспектів добровольчої діяльності визначають необхідність комплексного аналізу соціально-психологічниххарактеристикдобровольців.

У сучасному суспільстві відбуваються такі зміни соціального характеру, які вимагають пильної уваги з точки зору оперативності превентивних заходів профілактики девіантної поведінки в середовищі молоді. Криза інституту праці, реформи вищої освіти, зростання прагматичних і матеріальних цінностей у середовищі молоді, зокрема студентської молоді, приводять нас до необхідності шукати нові ресурси для вирішення соціальних проблем суспільства.

Цікаві дані отримані в роботах Y. Breitsohl, N. Ehrig [2]. Вчені з'ясували, що у працівників організацій, які є добровольцями у позаробочий час, найкраще виражені мотиви альтруїстичних цінностей та уникнення будь-якого негативного впливу, але присутній незначний мотив досягнення кар'єрного зростання порівняно з працівниками, які не $€$ добровольцями. Ще одними важливими аспектами з точки зору аналізу провідних детермінант особистісного розвитку волонтерів, які здобувають фах і вже отримали спеціальність, $€$ розуміння специфіки мотивації для занять добровольчою діяльністю, бажання висловити свої значущі цінності та їх позитивна кореляція з організаційної прихильністю. Формування мотиваційних передумов відбувається під час професіоналізації молоді.

В аналітичному огляді дисертаційних досліджень волонтерської діяльності в закладах вищої освіти, зробленому Н.В. Грувером, розглядається блок питань, пов'язаних з організацією волонтерської діяльності [7]. Автор зазначає, що волонтерська діяльність, яка організовується в закладах вищої освіти, розглядається як «важливий ресурс професійного та особистісного розвитку майбутніх фахівців» [7]. Необхідно інтегрувати діяльність щодо організації добровольчих ініціатив молоді в освітнє середовище ЗВО, це забезпечить найбільш високий рівень соціально-педагогічного ефекту волонтерства.

На думку Л.С. Кирилової, добровольча практика як одна з форм професійної підготовки студентів, має бути яскраво вираженим освітнім потенціалом. Автор зазначає, що формування професійних умінь і навичок у процесі добровольчої практики найбільш ефективно відбувається за реалізації низки педагогічних умов, серед яких можна виділити такі:

- зміст добровольчої практики має розроблятися в тісному взаємозв'язку з основними напрямами майбутньої професійної діяльності;

- в добровольчій практиці використовуються активні форми й методи навчання, що забезпечують реалізацію суб'єктної позиції студента [8].

Ми вважаємо, що умови освітнього середовища, в яких відбувається формування професійних компетентностей та особистісних характеристик волонтерів, є головними індикаторами успішності створення комплексу соціально-психологічних характеристик учасників волонтерської діяльності. Також можемо виділити такі характеристики комплексу організаційно-педагогічних умов, концентруючи потенціал добровольчої діяльності студентів: 
- залучення студентів у соціально значущу діяльність;

- цілеспрямований супровід добровольчих ініціатив, орієнтований на формування соціальних компетентностей, особистісний розвиток, удосконалення професійних комунікаційних навичок, ціннісно-емоційної спрямованості молоді;

- реалізація соціальних проєктів у вигляді не тільки разових акцій, але й довгострокових системнихпроєктів, якіпередбачаютькомандну роботу, диференційований функціонал учасників проєкту, організацію міжсекторної взаємодії під час реалізації проєкту (співпраця і підтримка представників органів виконавчої влади, некомерційних організацій, засобів масової інформації та всіх зацікавлених сторін).

Волонтерська діяльність забезпечує соціально позитивний ефект прояву молоддю своїх особистісних якостей у ситуаціях реалізації самостійних ініціативних проєктів [6].

J.E. Booth, K.W. Patk, T.M. Glomb досліджували тенденцію підвищення інтересу роботодавців до взаємодії з добровольцями, розглядали можливості створення обмінних процесів між волонтерськими організаціями та працівниками. Діяльністьякволонтерів, надумкуавторів, є додатковим стимулом для працівників організацій, позитивно впливає на сприйняття роботи, придбання нових навичок працівниками, визнання керівника, що є важливим чинником управління людськими ресурсами [1].

Важливим аспектом організації добровольчої діяльності $€$ наявність в організаціях стратегій корпоративної соціальної відповідальності. Багато підприємств вносять значні ресурси в місцеві спільноти, отримуючи більш кваліфіковану робочу силу і підвищені репутаційні переваги [3].

Щодо освітніх організацій, то, безумовно, безперервне освітнє середовище, інститути соціального наставництва, залучення школярів у добровольчі ініціативи спільно зі студентами сприяють підвищенню іміджу освітньої організації, розумінню можливостей не тільки отримати професійні компетентності, але й пройти різні форми соціальної практики, що організовуються через волонтерство. В цьому контексті можна розглянути постулати концепції відповідальності і значення відносин у колективі, зокрема молодіжному [4].

Досліджуючи педагогічний потенціал добровольчої діяльності в соціалізації студентської молоді, Л.Є. Сікорська зазначає, що структура добровольчої діяльності відображає іiї моральний потенціал, будучи сферою турботи, уваги, соціальної участі та допомоги [9]. Як об'єкт добровольчої діяльності виступають проблемні соціально-гуманітарні явища, предметом є допомога як технологія соціального сприяння й участі.
У сучасному світі волонтерство є важливим компонентом успішного соціального розвитку, здатним сприяти вирішенню актуальних соціально-економічних проблем держави і підвищити якість життя людей. Діяльність добровольчих об'єднань аналогічна діяльності благодійних спільнот. У таких спільнотах забезпечується не тільки спільна участь молоді у суспільно значущі заходи і творчі справи, але й спільне проживання ними різних ситуацій взаємодії з опорою на «кодекс честі» (поваги, рівності, вірності, допомоги товаришам, чесності) та інші моральні принципи, які функціонують у молодіжних групах. До того ж у подібних спільнотах з'являється реальна можливість «не найпопулярнішим у звичному середовищі однолітків» молодим людям змінити для них життєву ситуацію, стати по-справжньому прийнятим у групі однодумців і нових друзів, заслужити в них повагу і визнання. Створення спеціальних умов саме в добровольчих об'єднаннях може підвищити у молодих людей рівень їх соціальної активності, отже, збільшити можливість їх успішної самореалізації в подальшому.

Концептуально важливо сьогодні, в умовах підвищеної уваги до добровольчої діяльності та питань її організації, забезпечити зрозумілість у питаннях адаптації теоретичних положень і концептів щодо цього проблемного поля до практичної діяльності. Це дасть змогу оптимально вибудовувати системну роботу в питаннях організації добровольчої діяльності, удосконалювати механізми міжсекторної взаємодії в галузі волонтерства.

Головним фактором розвитку волонтерства є створення лідерських програм, здатних виявляти серед учасників цих заходів молодих людей, які можуть шляхом свого особистого прикладу залучити до соціально значимих практик інших людей, спочатку своє близьке оточення, а згодом і більш широкі кола суспільства. Пошук таких людей займає чимало часу, а розвиток і виховання такого суб'єкта діяльності має ще більш невизначений характер. Ми згодні з твердженням, що ці причини лежать в основі того, що така діяльність має сьогодні фрагментарний характер. Добровольча діяльність характеризується різною формою участі, отже, різним ступенем стійкості. В основі стійкості лежить мотивація молодих людей, відповідно, важливим аспектом в організації добровольчої діяльності $€$ психологічний супровід цієї роботи з молоддю.

У перспективі завданням діяльності волонтерської спільноти $€$ забезпечення реалізації принципу «від сильної держави до сильного суспільства» [5].

Висновки 3 проведеного дослідження. На основі отриманих результатів можна зробити висновок про наявність комплексу про- 
відних детермінантів соціально-психологічного розвитку учасників добровольчого руху, описані характеристики соціально-психологічного портрета волонтера. Можна відзначити, що дослідження дало змогу достовірно визначити комплекс особистісних детермінант, які $€$ домінантними для молоді, що займається волонтерською діяльністю. Особливу значущість отримані результати мають з точки зору організації роботи з молодіжним співтовариством, залучення молоді до активної соціально перетворюючої добровольчої діяльності, що сприяє формуванню ціннісно-смислових характеристик особистості.

\section{ЛІТЕРАТУРA:}

1. Booth J.E., Park K.W., Glomb T.M. Employersupported volunteering benefits: Gift exchange among employers, employees, and volunteer organizations. Human Resource Management. 2009. Vol. 48. Issue 2. P. 227-249.

2. Breitsohl Y., Ehrig N. Commitment through Employee Volunteering: Accounting for the Motives of Inter-Organisational Volunteers. Applied Psychology. 2017. Vol. 66. Issue 2, 1. P. 260-289.

3. Cook J., Burchell J. Bridging the Gaps in Employee Volunteering: Why the Third Sector Doesn't Always Win.
Nonprofit and Voluntary Sector Quarterly. 2018. Vol. 47. Issue 1. P. 165-184.

4. Faldetta G.A relational approach to responsibility in organizations: The logic of gift and Lévinasian ethics for a "corporeal" responsibility. Culture and Organization. 2015. № 24 (3). P. 1-25.

5. Kadyrov K. The history of public volunteer bodyguards (PVB) or volunteer policemen in Uzbekistan. Theoretical \& applied science. 2018. № 2 (58). P. 43-45.

6. Okun M.A., Schultz A. Age and motives for volunteering: testing hypotheses derived from socioemotional selectivity theory. Psychology and aging. 2003. Vol. 18. № 2. P. 231-239. URL: https://elibrary.ru/item. asp?id=8301309.

7. Грувер Н.В. Аналитический обзор диссертационных исследований добровольческой (волонтерской) деятельности в учреждениях высшего образования. Научное обозрение. Педагогические науки. 2017. № 1. С. 77-87.

8. Кириллова Л.С. Формирование профессиональных умений и навыков у будущих бакалавров социальной работы в процессе добровольческой практики : дисс. ... канд. пед. наук. Ставрополь, 2004.

9. Сикорская Л.Е. Педагогический потенциал добровольческой деятельности в социализации студенческой молодежи : дисс. ... докт. пед. наук. Елец, 2011. 